\title{
Head, facial and neck cooling as per-cooling modalities to improve exercise performance in the heat: A narrative review and practical applications
}

\author{
Yinhang Cao ${ }^{1, \#}$, Tze-Huan Lei ${ }^{2, \#}$, Faming Wang ${ }^{3, *}$, Bin Yang ${ }^{4}$ \\ ${ }^{1}$ School of Physical Education and Sport Training, Shanghai University of Sport, Shanghai, \\ 200438, China \\ ${ }^{2}$ College of Physical Education, Hubei Normal University, Huangshi, 435002, China \\ ${ }^{3}$ School of Architecture and Art, Central South University, Changsha, 410018, China \\ ${ }^{4}$ School of Building Services Science and Engineering, Xi'an University of Architecture and \\ Technology, Xi'an, 710055, China
}

\#These authors contributed equally to this work.

*Corresponding author, Prof. Faming Wang, e-mail: dr.famingwang@ gmail.com.

\section{ORCID:}

Dr. Yinhang Cao, 0000-0003-2323-3707

Dr. Tze-Huan Lei, 0000-0003-3157-099X

Dr. Faming Wang, 0000-0002-2945-4685

Word count: $\sim 3767$ words (key points, abstract, figures, tables and references excluded)

Running head: Neck, head and facial cooling on exercise performance

Postal address: School of Architecture and Art, Central South University, New Campus, Changsha, 410018, China

Tel.: +(86) 173-1805-0393 


\section{Key points}

- Neck cooling during exercise is effective to enhance endurance performance for endurance athletes in the heat.

- Neck cooling during exercise could improve repeated sprint performance for team sport athletes in the heat.

- Head, neck \& facial cooling could largely reduce local skin temperature and thereby improving local perceptual responses.

- Neck cooling is preferred over the head, facial \& combined head/facial \& neck cooling for both endurance and team sport athletes.

- It's challenging to adopt facial or head cooling to cool athletes during exercise due to inherent issues of practicality. 


\section{ABSTRACT (up to 250 words)}

It has been well established that athletic performance is greatly affected by environmental heat. Numerous studies have attempted to find reliable cooling strategies to improve athletic performance while exercising in the heat. Whole-body pre-cooling has been found to enhance endurance performance in both dry and humid heat. Nevertheless, positive physiological alternations induced by pre-cooling gradually disappear during exercise. Hence, there is a great need to find effective per-cooling strategies to improve athletic performance in the heat. Unfortunately, it's impractical to adopt pre-cooling approaches as a per-cooling modality to improve athletic performance due to inherent issues of practicality. Thus, a narrative review was conducted to examine the impact of head, neck and facial cooling on athletic performance in the heat. Based on current evidences, head, neck and facial cooling could greatly decrease local skin temperature at those areas where cooling was applied and thereby, local perceptual sensations were greatly enhanced. Neck cooling during exercise is found effective to improve athletic performance for both endurance and team sports athletes in the heat. Besides, neck cooling is preferred over the head, facial \& combined head/facial \& neck cooling for both endurance and team sport athletes in the heat from a practical application viewpoint. Research is lacking on the systematically selection of per-cooling modalities to improve athletic performance based on environmental conditions and nature of the sports activity. In addition, powerful but portable head, neck and facial cooling systems are urgently required to help athletes improving performance in the heat.

KEYWORDS: endurance performance; heat stress; thermoregulation; pre-cooling; percooling; cooling intensity 
medRxiv preprint doi: https://doi.org/10.1101/2021.05.31.21258125; this version posted June 3, 2021. The copyright holder for this preprint

\section{Introduction}

Current consensus $[1,2]$ clearly indicates that performing endurance exercise in an uncompensable heat stress environment imposes a greater thermoregulatory strain compared to cool or thermal neutral environment. This increase of thermoregulatory strain is mainly due to the inability to dissipate the metabolic heat via both dry and wet heat transfer, which consequently results in a higher core temperature $\left(\mathrm{T}_{\text {core }}\right)[2]$. Higher $\mathrm{T}_{\text {core }}$ elevates both thermal perceptual and cardiovascular strains, which subsequently causes the voluntary reduction of power output [3] or pre-mature fatigue as assessed by the time to exhaustion approach [4].

Whole-body precooling by using water-immersion technique has been found to enhance endurance performance in both dry and humid heat as assessed by time to exhaustion $[5,6]$ or by using the self-selected pace $[7,8]$. This increase of endurance performance is mainly due to physiological alternation (i.e., lower resting core and skin temperatures) induced by precooling [5] which thereby reduces cardiovascular and perceptual strains when performing prolonged endurance exercise in the heat. These improvements in thermoregulatory function along with a lower perceptual strain greatly enhance endurance performance in an uncompensable heat stress environment [9]. Nevertheless, the major limitations associated with whole-body pre-cooling are: time consuming and lack of real world-application because this requires a prolonged time to achieve the desired results. Also, the majority of reported whole-body cooling strategies are difficult to be adopted during exercise because such strategies are mainly designed for cooling inactive athletes. Furthermore, it's common that the desired physiological status (e.g., enhanced heat storage capacity) induced by the use of a specific precooling strategy disappears rapidly during exercise and thereby almost no superior benefits could be registered on the alleviation of athletes' thermal strain as compared to control trials. Recently the use of per-cooling strategy to cool athletes during exercise became of greater interest. In fact, when performing exercise in an uncompensable heat stress environment (i.e., humid heat), per cooling is just as important as pre-cooling as it is effective to reduce the rise of $\mathrm{T}_{\text {core }}$ during exercise $[10,11]$ and thereby reducing the risk of heat related injuries for all athletes.

To date, per-cooling has been extensively used for reducing athletes' thermal strain during exercise because there is a great need to help athletes dissipate metabolic heat during 
medRxiv preprint doi: https://doi.org/10.1101/2021.05.31.21258125; this version posted June 3, 2021. The copyright holder for this preprint

the exercise compared to resting or warming-up conditions. Per-cooling strategies have often been applied to local body regions such as the torso, head, face, and the neck. Cooling the head and neck regions are effective to mitigate perceptual strain and enhance physical performance in the heat [12-16]. Those two cooling interventions are based on the facts that the head/face and neck regions of the human body have greater alliesthesial response than the rest of the body, which can immediately result in the reduction of whole-body thermal discomfort when cold stimulus is applied to mild-heat stress individuals [17].This reduction of thermal perceptions subsequently enhances both endurance and repeated sprint ability in the heat without altering the thermoregulatory response [18]. Furthermore, the cooling areas of those regions are relatively small yet achieving similar ergogenic benefits as using wholebody pre-cooling using the water immersion approach. Due to these reasons, both cooling interventions (Head and neck cooling) are considered having more real-world implications than the traditional whole-body cooling intervention as it can provide both pre and percooling effect for endurance athletes as well as for team sport athletes. In addition, the cooling device for both neck and head/face cooling are easy to wear with minimal weight bearing, which can be beneficial for both team sport and endurance athletes, where the weight of the equipment may have a detrimental outcome on physical performance.

Although previous investigations [10, 13-15, 18] have eloquently elucidated that both head/face and neck cooling interventions can effectively enhance performance in the heat, those investigations do not specifically address whether those interventions can be applied to both team sport and endurance athletes. Furthermore, limited studies are available to describe the physiological and performances differences between such cooling interventions. Identifying a "one size fits all" cooling intervention for all athletes is necessary for the next upcoming sporting event such as the 2021 Tokyo Olympic games as it can enhance physical performance whilst reducing the thermoregulatory strain in an uncompensable heat stress environment. Due to the shortcoming investigation between head, facial and neck cooling on physical performance, the purpose of this narrative review is to investigate which cooling intervention is ideal for both endurance and team sport athletes in an uncompensable heat stress environment. In addition, this narrative review also comprehensively overviews the thermoregulatory and perceptual response of each cooling intervention and thus provides valuable recommendation for the general public as which cooling intervention is preferred when performing daily living activity in the summer time. Lastly, we hope by highlighting the unexplored issues would stimulate more mechanistic research in this area. 


\section{Literature search methods and considerations}

Literature searching was performed within the databases PubMed, MEDLINE, Scopus, Google Scholar and ProQuest up to May 2021. Keywords used for searching included neck cooling, carotid cooling, head cooling, facial cooling, exercise, per-cooling, pre-cooling, post-cooling, personal cooling, endurance performance, repeated sprint and time trial. Studies were included if one of the below criteria met:

- Participants were described as 'healthy' or 'active' and no known diseases that could affect the exercise performance or thermoregulation.

- Studies were performed at an ambient temperature of $\geq 20{ }^{\circ} \mathrm{C}$;

- Studies examined at least a type of cooling strategy that being applied to the head, face or the neck or any possible combination of these three body regions;

- Studies reported either physiological responses or perceptual responses or both;

- Studies that were published in the English language in peer-review journals, conference proceedings or published theses.

We did not include studies that used head, face, or/and neck cooling modalities on such occupational activities such as firefighting, farming, or construction work. Any study that did not report the test condition was also excluded. Two old studies published in 1970s and 1980s were excluded as well because we were not able to access to the full-text.

Our search found 32 references on "neck cooling" AND "exercise" AND "healthy", 22 results on "face cooling" AND "exercise" AND "healthy", 22 results on "head cooling" AND "exercise" AND "healthy", 15 results on "head and face cooling" AND "exercise" AND "healthy", 9 results on "head and neck cooling" AND "exercise" AND "healthy" and 7 results on "face and neck cooling" AND "exercise". Of those 107 studies, 64 references did not address the areas of interest. In Google Scholar and ProQuest databases, 5 relevant conference proceeding articles/extended abstracts and 1 relevant published thesis were found. Hence, a total of 49 studies have been included in this narrative review. 
medRxiv preprint doi: https://doi.org/10.1101/2021.05.31.21258125; this version posted June 3, 2021. The copyright holder for this preprint

Figure 1 depicts the co-occurrence map of the most frequent used keywords in the abstract and the full text of the 49 studies. The co-occurrence map illustrates the extent of keywords occurring simultaneously in the reviewed keyword volume. The connection between any two simultaneous keywords is represented by the network, while the frequency of a particular keyword is represented by its circle size. The dense network demonstrates that keywords such as "male", "female", "face", "head", "neck" , "body temperature", "skin temperature", and "heart rate" are used frequently and are correlated with almost every other keyword. Furthermore, most studies chose "young adult" subjects as their investigated groups.

\section{Neck cooling and exercise performance}

Table 1 shows the published studies on neck cooling and its performance on athletes while exercising in the heat [13-15, 18-36]. The most often used neck cooling approaches in the 23 documented literatures mainly include cooling collars, wet towels and ice bags. First, the use of neck cooling could greatly decrease the local skin temperature at the neck and thereby local thermal sensation at the neck was also significantly improved at the neck region, despite six out of 23 studies did not report the local neck temperature. Neck cooling via using a neck collar has been found to enhance both endurance and team sport performance in the heat $[13-15,18,19,28-30]$. Hence, cooling the neck may be the optimal site than the face or the head. This is evidenced by the fact that time to exhaustion, self-paced performance and repeated sprint ability [13-15, 18, 19] are all greater when wearing the cold neck collar compared to no cooling trial. This increase in physical performance with neck cooling may be due to the neck region has high alliesthesial response and close proximity to the thermoregulatory center, namely the insular cortex and so any cold stimulus can directly result in the immediate change of local thermal sensation (TS) and hence the rate of perceived exertion. This therefore results in the increase of self-selected pace or extend the time to reach volitional exhaustion. The increase of endurance performance with wearing cold neck collar is mainly perceptually mediated and its thermoregulatory response is different between time to exhaustion and self-selected pace approach.

When assessing endurance performance using the time to exhaustion approach, time to volitional exhaustion is significantly longer with the neck cooling collar compared to the 
medRxiv preprint doi: https://doi.org/10.1101/2021.05.31.21258125; this version posted June 3, 2021. The copyright holder for this preprint

control trial. However, this also corresponds to a higher core temperature at the time to exhaustion[14], leading to a conclusion that neck cooling may increase the chance of heat related illness as it masks the extent of thermal strain being perceived. However, this statement is in fact debatable as this approach deprives our thermoregulatory behavior, which has unlimited capacity to regulate our body temperature during exercise. Furthermore, time to exhaustion has poor face validity and cannot represent the actual endurance event due to its open-end design. Studies from self-selected pace indicated that neck cooling can enhance the overall power output without altering core temperature, heart rate and neuroendocrinological response $[13,15]$. This indicate that using our behavior response is able to counteract the false signal induced by the neck cooling and thereby prevent the excessive rise of core temperature in the heat. Therefore, neck cooling is an effective per cooling method to enhance endurance performance in the heat. However, it is worth noting that neck cooling may not work well if the duration of exercise is less than 15 min as Tyler et al. [13] showed that neck cooling was not effective to enhance physical performance in a 15 min time trial.

It is also worth mentioning that some studies (13 out of 23, Table 1) [13, 20-25, 31-36] indicate that neck cooling per se does not render any ergogenic benefit when performing prolonged exercise in the heat. Such great discrepancy can be attributed to the intensity of the cooling is not sufficient enough to alter the rate of perceived exertion (RPE), which is commonly believed as the important perceptual marker to determine central fatigue in the heat as it directly correlated with our arousal level [68]. In particular, the $\alpha / \beta$ wave ratio was elevated during hyperthermia and this has been linked to reduce our arousal level and contributes to the inability to maintain the desired power output during prolonged exercise in the heat.

\section{Head cooling and exercise performance}

A summary of 11 published literatures on head cooling and its impact on sports and exercise performance is listed in Table 2 [16, 37-45]. Interestingly, only four studied examined the local head temperature and all found that there was a pronounced temperature reduction at the head. Over half (6 out of 11 studies) studies did not examine 
medRxiv preprint doi: https://doi.org/10.1101/2021.05.31.21258125; this version posted June 3, 2021. The copyright holder for this preprint

the perceptual responses of athletes during head cooling. It could be inferred from 4 published work [38-41] that head cooling could potentially enhance endurance performance in the heat [38-41] but whether it can be applied to both endurance events and team sport setting requires further investigation. This is given by the fact that current studies (see Table 2) have yet to investigate whether head cooling can potentially enhance repeated sprint ability for team sport athletes in any given thermal environment. Furthermore, whether head cooling is able to enhance endurance performance in the heat still remains equivocal as the majority of studies revealed that head cooling renders no ergogenic benefits in the heat. Presently, there are very limited studies available on the effect of head cooling on self-selected pace in the heat. Such conflicting findings between the previous studies are once again related to the intensity of the cooling and this is directly related to the cooling materials being used inside the cooling cap or cooling helmet. It is possible that most of the previous studies have employed low cooling intensity for their study design and thus it was insufficient to alter the RPE response during exercise in the heat. On the other hand, some studies (Table 2) have revealed that when the cooling intensity is able to attenuate the rise of RPE, the increase of physical performance ensues $[16,40]$. Therefore, it is believed that head cooling with stronger cooling intensity could potentially alter our arousal level and thereby affecting our physical performance. However, this specific notion requires further justification.

-insert Table 2 about here

\section{Facial cooling and exercise performance}

The facial cooling and its performance outcomes are shown in Table 3. Of all 9 included studies, 8 of them examined either the forehead or the facial temperature. Five studied $[12,46$, 49-51] also examined the local perceptual sensations (thermal sensation and thermal discomfort). Similar to the effect of neck and head cooling on the neck and head regions, facial cooling could greatly enhance the thermal sensation at the facial area and thermal discomfort at the face could be greatly alleviated as well. For physiological outcomes, although two studies [12, 46] have suggested that facial cooling seemingly enhance performance in the heat (Table 3), facial cooling may not fully render ergogenic benefits in the heat for both endurance and team sport athletes in the heat. This is given by the fact that 
medRxiv preprint doi: https://doi.org/10.1101/2021.05.31.21258125; this version posted June 3, 2021. The copyright holder for this preprint

there are no studies available in team sport athletes and facial cooling only reduced RPE at the end of the stage [50]. Such small decrement of RPE may not be large enough to elicit behavioral adaptation in highly trained subjects as their perceptual response is different from healthy population [61]. In particular, Stevens et al. [46] indicated that even in moderately trained subjects, facial cooling only improved running speed at the first 2-km but it was soon nullified thereafter. Furthermore, no studies are available to show whether facial cooling can potentially extend the time to exhaustion in well trained endurance athletes or with different levels of aerobic fitness. Those evidence from above support the notion that facial cooling may not be applied to well-trained subjects.

From the practical point of view, facial cooling also has a poor real-world implication to both endurance and team sport athletes as it is difficult to employ this during exercise. It is well noted that per cooling is just as important as pre-cooling especially when the environment is hot and humid. Therefore, facial cooling is not an ideal cooling method during exercise in a hot humid environment.

-insert Table 3 about here

\section{Combined head, neck and/or facial cooling \& exercise performance}

The impact of combined facial/head and neck cooling on the sports and exercise performance is presented in Table 4 [54-60]. Obviously, the combined hear/face and neck cooling could largely improve the thermal sensation and thermal discomfort at the cooling regions [54-59]. The effect of combined effect of either head and neck or facial and head cooling on exercise performance in the heat remains unclear and may not actually render any ergogenic benefits compared to neck cooling along despite a larger total cooling area in the combined cooling strategy as compared to the single cooling approach being applied to the face, neck or the head [61]. This is given by the fact that current literatures have yet to address the combined effect of either head and neck cooling or facial and head cooling on exercise performance as compared neck cooling along in the heat for both endurance and team sport athletes. Furthermore, by summarizing the current literatures from above (Table 1, Table 2 and Table 3), it is suggested that the combined cooling may not actually render any ergogenic benefits as the effect of both head and facial cooling on both endurance and 
medRxiv preprint doi: https://doi.org/10.1101/2021.05.31.21258125; this version posted June 3, 2021. The copyright holder for this preprint

(which was not certified by peer review) is the author/funder, who has granted medRxiv a license to display the preprint in perpetuity.

It is made available under a CC-BY-ND 4.0 International license .

repeated sprint performance remains equivocal. Lastly, from the practical perspective, combined cooling is considered having less real-world application than neck cooling along as it is relatively difficult to implement this cooling intervention during exercise in the heat.

Although the combined cooling intervention may not be suitable as a per cooling strategy for both endurance and team sport athletes in the heat, this cooling intervention may be effective as a post-cooling strategy after performing exercise in the heat as this may be able to compensate the withdrawal of thermoeffector and thereby reducing the magnitude of postexercise hyperthermia. In particular, occupational workers with protective clothing or American football players with multiple body armor may be beneficial from this intensive cooling intervention as compared to neck cooling along. However, this separate and combined effect have not been investigated and therefore warrants further investigation.

\section{Practical considerations}

By summarizing the current literatures to date (Tables 1,2, $3 \& 4$ ), neck cooling is preferred over head or facial cooling as it can be used before and during exercise in the heat for both endurance and team sport athletes [62]. Besides, head cooling is preferred over facial cooling as it can also be used as a pre and per cooling strategy in the heat. It is worth mentioning that the selection of cooling temperature from the neck cooling collar or cooling helmet needs to be individualised as each individual will have their own preferred cooling temperature but the cooling temperature needs to be great enough to alter the RPE whilst without causing further rise of core temperature. Furthermore, it is suggested that the endurance athletes should also utilise either the neck or head cooling intervention upon the completion of their race as it is necessary to compensate the effect of post-exercise hyperthermia especially when the heat stress environment is hot and humid [63].

Lastly, it is suggested that the cooling materials inside the cooling collar or the helmet should consider phase change materials (including ice) rather than the gel refrigerant because phase change materials provide stable cooling intensity than the gel refrigerant during phase 
medRxiv preprint doi: https://doi.org/10.1101/2021.05.31.21258125; this version posted June 3, 2021. The copyright holder for this preprint

change. Though soft gel could provide good flexibility when being applied to the body surface, its temperature changes throughout the entire application period. Particularly, soft gel refrigerant provides the most powerful cooling intensity at the very beginning but this cooling power gradually reduces with the time. In addition, the mass of phase change materials should be large in order to provide athletes an extended cooling duration during exercise. Other cooling strategies such as the use of wearable cooling fans and a liquid cooling neck collar may be applicable, their actual performance on the improvement of performance in exercising athletes requires further investigation, however.

\section{Directions for Future Research}

Whilst current studies have eloquently addressed the effect of neck, head, facial as well as the combined head $\&$ neck cooling on both endurance and team sport performance, there are three major unexplored issues that warrants further investigation. First, current studies did not specifically incorporate the effect of different cooling modes on local and whole-body thermal discomfort, thermal pleasant and skin wettedness in their research design. It is well known that those thermal perceptions could influence RPE and thereby affecting our physical performance in the heat $[12,64]$. Furthermore, those perceptual variables are important to dictate our thermoregulatory behavior $[12,65,66]$ and therefore it would be novel to investigate whether cooling per se would mask the signal to initiate our thermoregulatory behavior, which has the unlimited capacity to regulate our body temperature.

Second, previous studies do not consider the role of aerobic fitness on the effect of neck, head, facial and combined head \& neck cooling during the self-paced exercise in the heat. It is well known that well trained populations are more accustom to being thermally discomfort [67] than untrained individual when exercising in the heat and therefore additional cooling may not be ergogenic as compared to untrained individual. Indeed, previous studies mainly target endurance or team sport athletes and this could be the reason why some studies did not find any performance enhancement by using neck cooling during exercise.

Lastly, rationale on the selection of cooling devices in a given sports and exercise setting has not yet been well investigated. For instance, the cooling temperature of the device varies considerably ranging from $21{ }^{\circ} \mathrm{C}$ to $-80{ }^{\circ} \mathrm{C}$ and such variation of cooling temperature would undoubtfully alter our thermal perceptions and hence our exercise performance in the heat. 
Furthermore, to date, the selection of those cooling temperatures is not evidenced based, instead it is chosen without any supporting evidence from either the thermoregulatory or the perceptual response in the heat. Also, the mass of cooling materials, the type of cooling strategy (e.g., air cooling, phase change material cooling, evaporative cooling, \& liquid cooling), the design of the cooling devices (e.g., packing material, insulation between the cooling material and human skin, \& contact area) are far from clear. Those factors could greatly affect the cooling intensity as well as the cooling duration of the selected device. Thereby, their actual impact on the performance enhancement while exercising in various heat conditions could vary greatly. Therefore, those aforementioned issues warrant further investigation as this would extend our understanding on the effect of per cooling in both compensable or in uncompensable heat stress environment.

\section{Conclusions}

Neck, facial and head cooling could significantly reduce local skin temperature and thereby improves local perceptual sensations including thermal sensation and thermal discomfort on athletes while exercising in the heat. Neck cooling is an ideal per-cooling strategy than head or facial cooling for both endurance and team sport athletes. Furthermore, head cooling is preferred than facial cooling for endurance athletes but its efficacy on team sport athletes remains to be explored. Furthermore, it remains unclear whether the combined head, neck and/or facial cooling could bring a synergy effect on sports and exercise performance in the heat. Future investigations should extensively examine the potential of neck, head and facial cooling to enhance performance of male and female athletes while performing various types of sport and exercise activities in the heat. Besides, the design of powerful but portable head, neck and facial cooling systems is urgently required due to the great need to dissipate metabolic heat production during intensive sports activities.

Conflicts of interest The authors declare that they have no conflicts of interest relevant to the content of this review.

Funding No sources of funding were used to assist in the preparation of this article. 
medRxiv preprint doi: https://doi.org/10.1101/2021.05.31.21258125; this version posted June 3, 2021. The copyright holder for this preprint (which was not certified by peer review) is the author/funder, who has granted medRxiv a license to display the preprint in perpetuity. It is made available under a CC-BY-ND 4.0 International license .

Author contributions Original idea: FW; Development and formulation of concept: FW, THL, YC \& BY; Draft: YC, THL, FW; Critical revision: THL, FW \& BY. 
medRxiv preprint doi: https://doi.org/10.1101/2021.05.31.21258125; this version posted June 3, 2021. The copyright holder for this preprint (which was not certified by peer review) is the author/funder, who has granted medRxiv a license to display the preprint in perpetuity.

It is made available under a CC-BY-ND 4.0 International license .

\section{References}

1. Racinais S, Alonso J-M, Coutts AJ, Flouris AD, Girard O, González $\square$ Alonso J, et al. Consensus recommendations on training and competing in the heat. Scand J Med Sci Sports. 2015;25:6-19.

2. Sawka MN, Leon LR, Montain SJ, Sonna LA. Integrated physiological mechanisms of exercise performance, adaptation, and maladaptation to heat stress. Compr Physiol. 2011;1(4):1883-928.

3. Périard JD, Cramer MN, Chapman PG, Caillaud C, Thompson MW. Cardiovascular strain impairs prolonged self-paced exercise in the heat. Exp Physiol. 2011;96(2):134-44.

4. Galloway SD, Maughan RJ. Effects of ambient temperature on the capacity to perform prolonged cycle exercise in man. Med Sci Sports Exerc. 1997;29(9):1240-9.

5. González-Alonso J, Teller C, Andersen SL, Jensen FB, Hyldig T, Nielsen B. Influence of body temperature on the development of fatigue during prolonged exercise in the heat. $\mathrm{J}$ Appl Physiol. 1999;86(3):1032-9.

6. Hasegawa H, Takatori T, Komura T, Yamasaki M. Combined effects of pre-cooling and water ingestion on thermoregulation and physical capacity during exercise in a hot environment. J Sports Sci. 2006;24(1):3-9.

7. Booth J, Marino F, Ward JJ. Improved running performance in hot humid conditions following whole body precooling. Med Sci Sports Exerc. 1997;29(7):943-9.

8. Kay D, Taaffe DR, Marino FE. Whole-body pre-cooling and heat storage during selfpaced cycling performance in warm humid conditions. J Sports Sci. 1999;17(12):937-44.

9. Marino F. Methods, advantages, and limitations of body cooling for exercise performance. Br J Sports Med. 2002;36(2):89-94.

10. Stevens CJ, Taylor L, Dascombe BJ. Cooling During Exercise: An Overlooked Strategy for Enhancing Endurance Performance in the Heat. Sports Med. 2017;47(5):829-41.

11. Hasegawa H, Takatori T, Komura T, Yamasaki M. Wearing a cooling jacket during exercise reduces thermal strain and improves endurance exercise performance in a warm environment. J Streng Condition Res. 2005;19(1):122-8.

12. Schlader ZJ, Simmons SE, Stannard SR, Mündel T. The independent roles of temperature and thermal perception in the control of human thermoregulatory behavior. Physiol Behav. 2011;103(2):217-24.

13. Tyler CJ, Wild P, Sunderland C. Practical neck cooling and time-trial running performance in a hot environment. Eur J Appl Physiol. 2010;110(5):1063-74. 
medRxiv preprint doi: https://doi.org/10.1101/2021.05.31.21258125; this version posted June 3, 2021. The copyright holder for this preprint (which was not certified by peer review) is the author/funder, who has granted medRxiv a license to display the preprint in perpetuity. It is made available under a CC-BY-ND 4.0 International license .

14. Tyler CJ, Sunderland C. Cooling the neck region during exercise in the heat. J Athl Train. 2011;46(1):61-8.

15. Tyler CJ, Sunderland C. Neck cooling and running performance in the heat: single versus repeated application. Med Sci Sports Exerc. 2011;43(12):2388-95.

16. Ansley L, Marvin G, Sharma A, Kendall MJ, Jones DA, Bridge MW. The effects of head cooling on endurance and neuroendocrine responses to exercise in warm conditions. Physiol Res. 2008;57(6):863-72.

17. Cotter JD, Taylor NA. The distribution of cutaneous sudomotor and alliesthesial thermosensitivity in mildly heat-stressed humans: an open-loop approach. J Physiol. 2005;565:335-45.

18. Sunderland C, Stevens R, Everson B, Tyler CJ. Neck-cooling improves repeated sprint performance in the heat. Front Physiol. 2015;6:314.

19. Minniti A, Tyler CJ, Sunderland C. Effects of a cooling collar on affect, ratings of perceived exertion, and running performance in the heat. Eur $J$ Sport Sci. 2011;11(6):419-29.

20. Moss JN, Trangmar SJ, Mackenzie RWA, Tyler CJ. The effects of pre- and per-cooling interventions used in isolation and combination on subsequent 15-min time-trial cycling performance in the heat. J Sci Med Sport. 2021; doi:10.1016/j.jsams.2021.04.006.

21. Bright FM, Chaseling GK, Jay O, Morris NB. Self-paced exercise performance in the heat with neck cooling menthol application, and abdominal cooling. J Sci Med Sport. 2019;22:371-7.

22. Cuttell SA, Kiri V, Tyler C. A comparison of 2 practical cooling methods on cycling capacity in the heat. J Athl Train. 2016;51:525-32.

23. Galpin AJ, Bagley JR, Whitcomb B, Wiersma LD, Rosengarten J, Coburn JW, Judelson DA. Effects of intermittent neck cooling during repeated bouts of high-intensity exercise. Sports. 2016;4:38.

24. Ando S, Komitama T, Sudo M, Kiyonaga A, Tanaka H, Higaki Y. The effects of temporal neck cooling on cognitive function during strenuous exercise in a hot environment: a pilot study. BMC Res Notes. 2015;8:202.

25. Lee JKW, Koh ACH, Koh SXT, Liu GJX, Nio AQX, Fan PWP. Neck cooling and cognitive performance following exercise-induced hyperthermia. Eur J Appl Physiol. $2014 ; 114: 375-84$.

26. Desai T, Bottoms L. Neck cooling improves table tennis performance amongst young national level players. Sports. 2017;5:19. 
medRxiv preprint doi: https://doi.org/10.1101/2021.05.31.21258125; this version posted June 3, 2021. The copyright holder for this preprint (which was not certified by peer review) is the author/funder, who has granted medRxiv a license to display the preprint in perpetuity. It is made available under a CC-BY-ND 4.0 International license .

27. Zhang Y, Nepocatych S, Katica CP, et al. Effect of half time cooling on thermoregulatory responses and soccer-specific performance test. Monten J Sports Sci Med. 2014;1:17-22.

28. Tyler CJ, Sunderland C. Neck cooling during exercise in the heat improves subsequent treadmill time-trial performance. Med Sci Sport Exerc. 2008;40:S368.

29. Colvin DP, Lokody T. Development of a macroPCM neck cooling collar for athletes and runners. Proc. IMECE'03, ASME Int Mech Eng Cong, Washington DC, No. 15-21, 2003, pp.1-2.

30. Gabryś J, Pieniazek W, Olejnik I, Pogorzelska T, Karpe J. Effects of local cooling of the neck on circulatory responses in men subjected to physical exercise in hyperthermia. Biol Sport. 1993;10:167-71.

31. Chalmers S, Siegler J, Lovell R, Lynch G, Gregson W, Marshall P, Jay O. Brief in-play cooling breaks reduce thermal strain during football in hot conditions. J Sci Med Sport. 2019:22:912-7.

32. Hamada S, Torii M, Szygula Z, Adachi K. Effect of partial body cooling on thermophysiological responses during cycling work in a hot environment. $\mathrm{J}$ Therm Biol. 2006;31:194-207.

33. Torii M, Adachi K, Miyabayashi T, Arima T, Iwashita M. Effect of bilateral carotid cooling with an ice pack on thermal responses during bicycle exercise. Environ Ergon. 2005;3:113-119.

34. Bouskill L, Parsons K. Effectiveness of a neck cooling personal conditioning unit at reducing thermal strain during heat stress. In: Robertson SA ed. Proc Ann Conf Ergon Soc, Apr. 1-12, 1996, Leicester, UK, pp.236-42.

35. Gordon NF, Bogdanffy GM, Wilkinson J. Effect of a practical neck cooling device on core temperature during exercise. Med Sci Sports Exerc. 1990;22:245-9.

36. Kielblock AJ, van Rensburg JP, Franz RM. Body cooling as a method for reducing hyperthermia: an evaluation of techniques. S Af Med J. 1986;69:378-80.

37. Levels K, Teunissen LPJ, de Haan A, de Koning JJ, van Os B, Daanen HAM. Effect of warm-up and precooling on pacing during a $15-\mathrm{km}$ cycling time trial in the heat. Int $\mathrm{J}$ Sport Physiol Perform. 2013;8:307-11.

38. Coelho LGM, Ferreira-Júnior JB, Williams TB, Maia-Lima A, Borba DA, Silva CD, et al. Head pre-cooling improves $5-\mathrm{km}$ time-trial performance in male amateur runners in the heat. Scand J Med Sci Sports. 2021;doi/10.1111/sms.13985. 
medRxiv preprint doi: https://doi.org/10.1101/2021.05.31.21258125; this version posted June 3, 2021. The copyright holder for this preprint

39. Walters P, Thom N, Libby K, Edgren S, Azadian A, Tannous D, Sorenson E, Hunt B. The effect of intermittent head cooling on aerobic performance in the heat. J Sport Sci Med. 2017;16:77-83.

40. Minett GM, Duffield R, Marino FE, Portus M. Volume-dependent response of precooling for intermittent-sprint exercise in the heat. Med Sci Sport Exerc. 2011;43:1760-9.

41. Hyde JL. The influence of head cooling combined with various cooling modalities on cooling rate after exercise in the heat. Master Thesis, University of Connecticut, 2015.

42. Desruelle AV, Candas V. Thermoregulatory effects of three different types of head cooling in humans during a mild hyperthermia. Eur J Appl Physiol. 2000;81:33-9.

43. Watanuki S. Effects of head cooling on cardiovascular and body temperature responses during submaximal exercise. Ann Physiol Anthrop. 1993;12:327-33

44. Katsuura T, Ise N, Onoda H, Okada A, Kikuchi Y. Effect of head cooling on man at rest and during exercise under heat stress. Ann Physiol Anthrop. 1989;8:49-50.

45. Greenleaf JE, van Beaumont W, Brock PJ, Montgomery LD, Morse JT, Shvartz E, Kravik S. Fluid-electrolyte shifts and thermoregulation: rest and work in heat with head cooling. Aviat Space Environ Med. 1980;51:747-53.

46. Stevens CJ, Kittel A, Sculley DV, Callister R, Taylor L, Dascombe BJ. Running performance in the heat is improved by similar magnitude with pre-exercise cold-water immersion and mid-exercise facial water spray. J Sport Sci. 2017;35:798-805.

47. Schlader ZJ, O'Leary MC, Sackett JR, Johnson BD. Face cooling reveals a relative inability to increase cardiac parasympathetic activation during passive heat stress. Exp Physiol. 2018;103:701-13.

48. Schlader ZJ, Coleman GL, Sackett JR, Sarker S, Johnson BD. Sustained increases in blood pressure elicited by prolonged face cooling in humans. Am J Physiol Regul Integr Comp Physiol. 2016;111:R643-8.

49. Mündel T, Bunn SJ, Hooper PL, Jones DA. The effects of face cooling during hyperthermic exercise in man: evidence for an integrated thermal, neuroendocrine and behavioural response. Exp Physiol. 2007;92(1):187-95.

50. Mündel T, Hooper PL, Bunn SJ, Jones DA. The effects of face cooling on the prolactin response and subjective comfort during moderate passive heating in humans. Exp Physiol. 2006;91:1007-14.

51. Armanda-da-Silva PAS, Woods J, Jones DA. The effect of passive heating and face cooling on perceived exertion during exercise in the heat. Eur J Appl Physiol. 2004;91:563-71. 
medRxiv preprint doi: https://doi.org/10.1101/2021.05.31.21258125; this version posted June 3, 2021. The copyright holder for this preprint (which was not certified by peer review) is the author/funder, who has granted medRxiv a license to display the preprint in perpetuity. It is made available under a CC-BY-ND 4.0 International license .

52. Williams PA, Kilgour RD. Cardiovascular responses to facial cooling during low and moderate intensity exercise. Eur J Appl Physiol Occup Physiol. 1993;67:53-8.

53. Kratzing CC, Cross RB. Effects of facial cooling during exercise at high temperature. Eur J Appl Physiol Occup Physiol. 1984;53:118-20.

54. Wiewelhove T, Conradt F, Rawlins S, et al. Effects of in-play cooling using simulated tennis match pay in the heat on performance, physiological and perceptual measures. $\mathrm{J}$ Sports Med Phys Fitness. 2021;61(3):372-9.

55. Simmons SE, Mündel T, Jones DA. The effects of passive heating and head-cooling on perception of exercise in the heat. Eur J Appl Physiol. 2008;104:281-8.

56. Palmer CD, Sleivert GG, Cotter JD. The effects of head and neck cooling on thermoregulation, pace selection, and performance. In: Proc Australian Physiol Pharmacol Soc, 2001;32(Suppl 1):122.

57. Gordon RJFH, Tillin NA, Tyler CJ. The effect of head and neck per-cooling on neuromuscular fatigue following exercise in the heat. Appl Physiol Nutr Metab. 2020;45(11):1238-46.

58. Goosey-Tolfrey V, Diaper NJ, Crosland J, Tolfrey K. Fluid intake during wheelchair exercise in the heat: effects of localized cooling garments. Int J Sport Physiol Perform. 2008;3:145-56.

59. Simmons SE, Saxby BK, McGlone FP, Jones DA. The effect of passive heating and head cooling on perception, cardiovascular function and cognitive performance in the heat. Eur J Appl Physiol. 2008;104:271-80.

60. Ronald B, Shapiro R, Murphy M, Levenhagen D. Effectiveness of a commercial headneck cooling device. J Strength Cond Res. 1999;13:198-205.

61. Douzi W, Dugué B, Vinches L, Al Sayed C, Hallé, Bosquet L, Dupuy O. Cooling during exercise enhances performance, but the cooled body areas matter: a systematic review with meta-analyses. Scand J Med Sci Sports. 2019;29:1660-76.

62. Ruddock A, Robbins B, Tew G, Bourke L, Purvis A. Practical cooling strategies during continuous exercise in hot environments: a systematic review and meta-analysis. Sports Med. 2017;47:517-32.

63. Selkirk GA, McLellan TM. Influence of aerobic fitness and body fatness on tolerance to uncompensable heat stress. J Appl Physiol. 2001;91(5):2055-63.

64. Vargas NT, Chapman CL, Sackett JR, Abdul-Rashed J, McBryde M, Johnson BD, et al. Thermal behavior remains engaged following exercise despite autonomic thermoeffector withdrawal. Physiol Behav. 2018;188:94-102. 
65. Schlader ZJ, Stannard SR, Mündel T. Evidence for thermoregulatory behavior during self-paced exercise in the heat. J Therm Biol. 2011;36(7):390-6.

66. Vargas NT, Chapman CL, Johnson BD, Gathercole R, Schlader ZJ. Skin wettedness is an important contributor to thermal behavior during exercise and recovery. Am J Physiol Regul Integr Comp Physiol. 2018;315(5):R925-33.

67. Tikuisis P, McLellan TM, Selkirk G. Perceptual versus physiological heat strain during exercise-heat stress. Med Sci Sports Exerc. 2002;34(9):1454-61.

68. Hasegawa H, Cheung SS. Hyperthermia effects on brain function and exercise capacity. J Phys Fitness Sports Med. 2013;2(4):429-38. 
medRxiv preprint doi: https://doi.org/10.1101/2021.05.31.21258125; this version posted June 3, 2021. The copyright holder for this preprint (which was not certified by peer review) is the author/funder, who has granted medRxiv a license to display the preprint in perpetuity.

Figure captions

Figure 1 Co-occurrence map of frequently used keywords from the 49 published references. 
medRxiv preprint doi: https://doi.org/10.1101/2021.05.31.21258125; this version posted June 3, 2021. The copyright holder for this preprint (which was not certified by peer review) is the author/funder, who has granted medRxiv a license to display the preprint in perpetuity.

$$
\text { It is made available under a CC-BY-ND } 4.0 \text { International license. }
$$

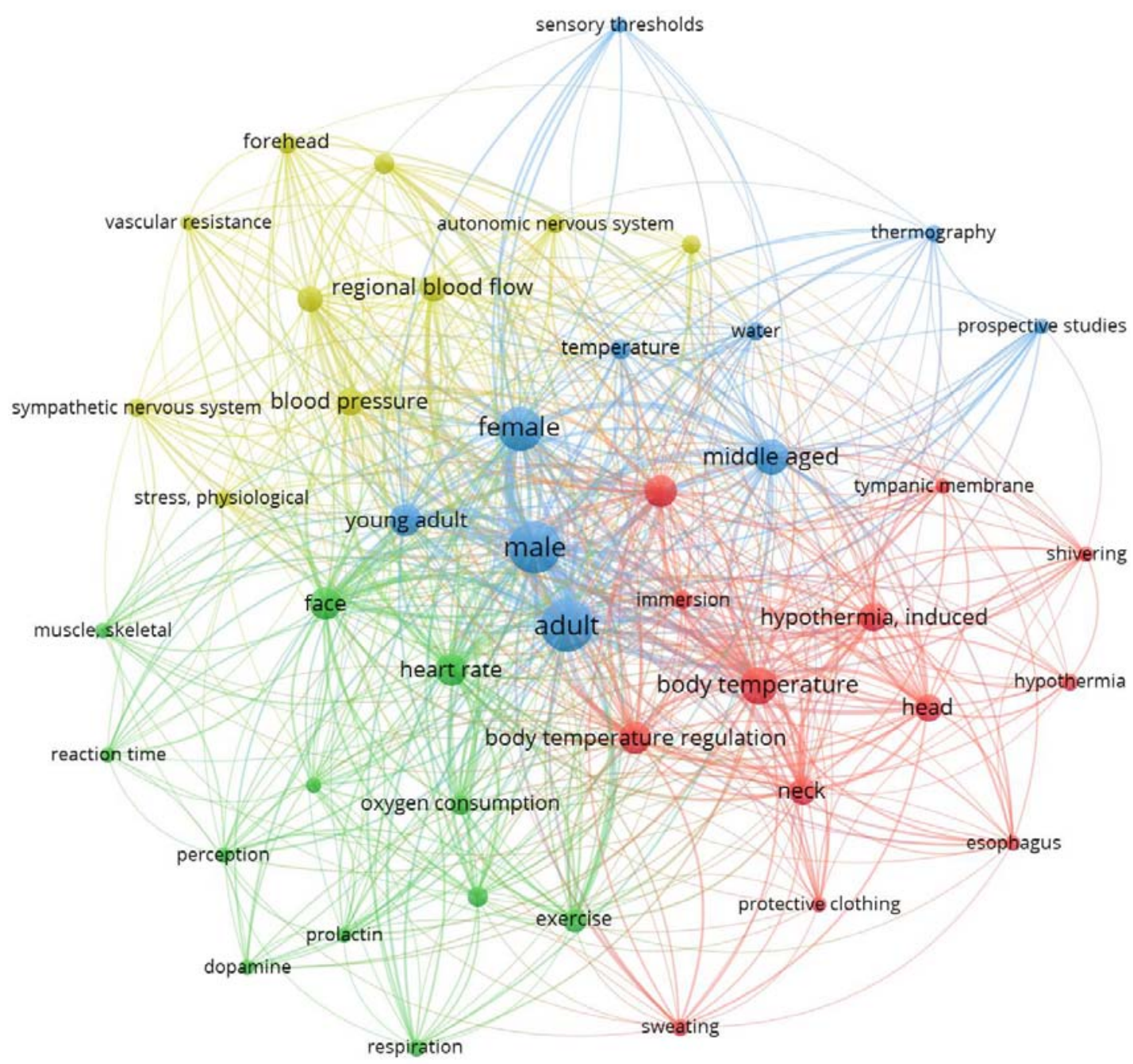




\section{Table captions}

Table 1 Effect of neck cooling on thermoregulatory responses and physical performance in the heat

Table 2 Effect of head cooling on thermoregulatory responses and physical performance in the heat

Table 3 Effect of facial cooling on thermoregulatory responses and physical performance in the heat

Table 4 Effect of combined neck, head and facial cooling on thermoregulatory responses and physical performance in the heat 
Table 1 Effect of neck cooling on thermoregulatory responses and physical performance in the heat

\begin{tabular}{|c|c|c|c|c|c|c|c|c|}
\hline Study & Subjects & $\begin{array}{l}\text { Ambient } \\
\text { conditions }\end{array}$ & $\begin{array}{l}\text { Cooling } \\
\text { interventions }\end{array}$ & Exercise protocol & $\mathbf{T}_{\text {neck }}$ & Perceptual outcomes & $\begin{array}{l}\text { Thermoregulatory } \\
\text { outcomes }\end{array}$ & $\begin{array}{l}\text { Performance } \\
\text { outcomes }\end{array}$ \\
\hline $\begin{array}{l}\text { Moss et al. } \\
\text { [20] }\end{array}$ & 9 males & $40^{\circ} \mathrm{C}, 50 \% \mathrm{RH}$, & $\begin{array}{l}\text { Cooling collar } \\
\left(155 \mathrm{~g}, 13.9^{\circ} \mathrm{C} \text {, replace every }\right. \\
15 \mathrm{~min})\end{array}$ & $\begin{array}{l}\text { Cycling } 45 \text { min at } 50 \% \\
\mathrm{VO}_{2 \max } \\
\text { followed by } 15 \text { min cycling } \\
\text { TT }\end{array}$ & $\downarrow$ & $\rightarrow \mathrm{TS} \& \mathrm{TD} \& \mathrm{RPE}$ & $\begin{array}{l}\rightarrow \mathrm{T}_{\text {core }} \& \mathrm{Tsk}, \rightarrow \\
\mathrm{HR}\end{array}$ & $\rightarrow$ Distance \\
\hline $\begin{array}{l}\text { Bright et al. } \\
\text { [21] }\end{array}$ & $\begin{array}{l}4 \text { females } \\
\& 8 \\
\text { males }\end{array}$ & $\begin{array}{l}34.4 \pm 0.7^{\circ} \mathrm{C}, 33 \pm 1 \% \\
\mathrm{RH}\end{array}$ & $\begin{array}{l}\text { Cooling collar (frozen at - } \\
1.3^{\circ} \mathrm{C} \text { replace every } 20 \mathrm{~min} \text { ) }\end{array}$ & $\begin{array}{l}\text { Cycling } 90 \text { min at } \mathrm{RPE}= \\
16\end{array}$ & $\downarrow$ & $\downarrow \mathrm{TS}$ & $\rightarrow \mathrm{T}_{\text {core }} \& \mathrm{Tsk}, \downarrow \mathrm{SR}$ & $\rightarrow$ Work load \\
\hline $\begin{array}{l}\text { Cuttell et al. } \\
\text { [22] }\end{array}$ & 8 males & $\begin{array}{l}35 \pm 0.1^{\circ} \mathrm{C} \\
50.1 \pm 0.7 \% \mathrm{RH}\end{array}$ & $\begin{array}{l}\text { Cooling collar }(155 \mathrm{~g}, \\
\text { freezed at }-24^{\circ} \mathrm{C} \text { for } 45-60 \\
\min , 1.1 \% \text { cooling area })\end{array}$ & Cycling TTE at $60 \%$ PPO & $\downarrow$ & $\downarrow \mathrm{TS}, \rightarrow \mathrm{RPE}$ & $\begin{array}{l}\rightarrow \mathrm{T}_{\text {core }} \& \mathrm{Tsk}, \rightarrow \\
\text { RPE \& HR \& SR }\end{array}$ & $\begin{array}{l}\rightarrow \text { Exercise time } \\
(30 \text { vs. } 28 \mathrm{~min})\end{array}$ \\
\hline $\begin{array}{l}\text { Galpin et al. } \\
\text { [23] }\end{array}$ & 13 males & $25 \pm 1^{\circ} \mathrm{C}, 53 \pm 1 \% \mathrm{RH}$ & $\begin{array}{l}\text { Wet ice bag ( } 1 \text { quart ice \& } \\
600 \mathrm{~mL} \text { room-temperature } \\
\text { water) was applied second } \\
\text { times among three exercise } \\
\text { bouts }\end{array}$ & $\begin{array}{l}\text { Two, } 5 \text {-min HEX bouts ( } 20 \\
\text { s maximal cadence cycling, } \\
\& 15 \text { s passive rest) at } 50 \% \\
\text { PP, \& TTE at } 30 \% \text { PP }\end{array}$ & $\downarrow$ & $\downarrow$ TS \& RPE & $\rightarrow \mathrm{HR} \& \mathrm{VO}_{2}$ & $\begin{array}{l}\rightarrow \text { Exercise time } \\
(66 \text { vs. } 74 \mathrm{~s})\end{array}$ \\
\hline $\begin{array}{l}\text { Ando et al. } \\
\text { [24] }\end{array}$ & 8 males & $35^{\circ} \mathrm{C}, 70 \% \mathrm{RH}$ & $\begin{array}{l}\text { Wet towel }\left(21^{\circ} \mathrm{C} \text { water } \&\right. \\
\text { fanning back neck of with a } \\
\text { small fan })\end{array}$ & $\begin{array}{l}\text { Ergometer cycling ( } 30-32 \\
\mathrm{~W} \text { [first } 5 \mathrm{~min} \text { ], increased } \\
\text { at } 20-21 \mathrm{~W} / \mathrm{min} \text { until } \\
\mathrm{HR}=160 \mathrm{bpm}) \text {, cycling } 10 \\
\text { min at } 160 \mathrm{bpm}\end{array}$ & $\downarrow$ & $\rightarrow \mathrm{RPE}$ & $\begin{array}{l}\downarrow \text { Tsk, } \rightarrow \text { Bla \& } \\
\text { WL }\end{array}$ & $\begin{array}{l}\rightarrow \text { Cognitive } \\
\text { function during } \\
\text { strenuous } \\
\text { exercise }\end{array}$ \\
\hline $\begin{array}{l}\text { Lee et al. } \\
\text { [25] }\end{array}$ & 12 males & $\begin{array}{l}30.2 \pm 0.3^{\circ} \mathrm{C}, 71 \pm 2 \% \\
\mathrm{RH}\end{array}$ & $\begin{array}{l}\text { Cooling collar }(120 \mathrm{~g} \text { gel } \\
\text { refrigerant frozen at }-80^{\circ} \mathrm{C} \\
\text { for }>24 \mathrm{~h} \text { [left in ambient } \\
\text { condition for } 5 \text { min before } \\
\text { use]) }\end{array}$ & $\begin{array}{l}\text { Running TTE at } 70 \% \\
\mathrm{VO}_{2 \max }\end{array}$ & $\downarrow$ & $\downarrow \mathrm{TS}, \rightarrow \mathrm{RPE}$ & $\begin{array}{l}\rightarrow \mathrm{T}_{\text {core }} \& \mathrm{Tsk}, \rightarrow \\
\text { HR \& S100ß \& WL }\end{array}$ & $\begin{array}{l}\rightarrow \text { Exercise time } \\
(71 \text { vs. } 67 \mathrm{~min})\end{array}$ \\
\hline
\end{tabular}




\begin{tabular}{|c|c|c|c|c|c|c|c|c|}
\hline $\begin{array}{l}\text { Tyler et al. } \\
\text { [13] }\end{array}$ & 8 males & $30^{\circ} \mathrm{C}, 50 \% \mathrm{RH}$ & $\begin{array}{l}\text { Cooling collar }(120 \mathrm{~g} \text { gel, } \\
\text { frozen at }-80^{\circ} \mathrm{C} \text { for } 24-28 \mathrm{~h} \\
\text { [left in air } 5 \mathrm{~min} \text { before } \\
\text { application]) }\end{array}$ & 15 min TT running & $\downarrow$ & $\downarrow \mathrm{TS}, \rightarrow \mathrm{RPE}$ & $\begin{array}{l}\rightarrow \mathrm{T}_{\text {core }}, \rightarrow \mathrm{HR} \& \\
\mathrm{SR}, \downarrow \mathrm{Wc}\end{array}$ & $\begin{array}{l}\rightarrow \text { Distance } \\
\text { ( } 3180 \text { vs. } 3239 \\
\text { m) }\end{array}$ \\
\hline $\begin{array}{l}\text { Tyler \& } \\
\text { Sunderland } \\
{[14]}\end{array}$ & 8 males & $\begin{array}{l}32.2 \pm 0.2^{\circ} \mathrm{C}, 53 \pm 2 \% \\
\mathrm{RH}\end{array}$ & $\begin{array}{l}\text { Cooling collar }(120 \mathrm{~g} \text { gel, } \\
\left.\text { placed at }-80^{\circ} \mathrm{C} \text { for } 24-28 \mathrm{~h}\right)\end{array}$ & $\begin{array}{l}\text { Running TTE at } 70 \% \\
\mathrm{VO}_{2 \max }\end{array}$ & $\downarrow$ & $\downarrow \mathrm{TS}, \rightarrow \mathrm{RPE}$ & $\begin{array}{l}\uparrow \mathrm{T}_{\text {core }} \uparrow \mathrm{HR} \rightarrow \mathrm{SR} \\
\& \mathrm{Wc} \& \mathrm{WL}\end{array}$ & $\begin{array}{l}\uparrow \text { Time by } 5 \\
\min (14 \%)\end{array}$ \\
\hline $\begin{array}{l}\text { Tyler et al. } \\
\text { [13] }\end{array}$ & 9 males & $30^{\circ} \mathrm{C}, 50 \% \mathrm{RH}$ & $\begin{array}{l}\text { Cooling collar }(120 \mathrm{~g} \text { gel, } \\
\text { frozen at }-80^{\circ} \mathrm{C} \text { for } 24-28 \mathrm{~h} \\
\text { [left in air } 5 \mathrm{~min} \text { before } \\
\text { application]) }\end{array}$ & $\begin{array}{l}\text { Running } 75 \text { min at } 60 \% \\
\mathrm{VO}_{2 \max } \\
\& 15 \text { min TT running }\end{array}$ & $\downarrow$ & $\downarrow \mathrm{TS}, \rightarrow \mathrm{RPE}$ & $\begin{array}{l}\rightarrow \mathrm{T}_{\text {core }}, \rightarrow \text { HR \& } \\
\text { Bla \& Gluc \& } \\
\text { Cortisol \& } \\
\text { Dopamine \& } \\
\text { Serotonin \& S100ß } \\
\& \text { PRL \& PV \& Wc }\end{array}$ & $\begin{array}{l}\uparrow \text { Distance by } \\
146 \mathrm{~m}(5 \%)\end{array}$ \\
\hline $\begin{array}{l}\text { Tyler \& } \\
\text { Sunderland } \\
{[15]}\end{array}$ & 7 males & $\begin{array}{l}30.4 \pm 0.1^{\circ} \mathrm{C}, 53 \pm 2 \% \\
\mathrm{RH}\end{array}$ & $\begin{array}{l}\text { Cooling collar (no change, } \\
\text { or change every } 30 \mathrm{~min} \text { ) } \\
\left(120 \mathrm{~g} \text { gel, frozen at }-80^{\circ} \mathrm{C}\right. \\
\text { for } 24-28 \mathrm{~h} \text { [left in air } 10 \\
\text { min before application]) }\end{array}$ & $\begin{array}{l}\text { Running } 75 \text { min at } 60 \% \\
\mathrm{VO}_{2 \max } \\
\& 15 \text { min TT running }\end{array}$ & $\downarrow$ & $\downarrow \mathrm{TS}, \rightarrow \mathrm{RPE}$ & $\begin{array}{l}\rightarrow \mathrm{T}_{\text {core }}(\mathrm{a} \& \mathrm{~b}), \rightarrow \\
\text { HR \& Bla \& Gluc } \\
\& \text { Wc \& SR }(\mathrm{a} \& \mathrm{~b})\end{array}$ & $\begin{array}{l}\text { (a) } \uparrow \text { Distance } \\
\text { by } 182 \mathrm{~m}(7 \%) \\
\text { (b) } \uparrow \text { Distance } \\
\text { by } 179 \mathrm{~m}(7 \%)\end{array}$ \\
\hline $\begin{array}{l}\text { Sunderland } \\
\text { et al. [18] }\end{array}$ & 7 males & $\begin{array}{l}33 \pm 0.2^{\circ} \mathrm{C}, 53 \pm 2 \% \\
\mathrm{RH}\end{array}$ & $\begin{array}{l}\text { Cooling collar }(120 \mathrm{~g} \text { gel } \\
\text { refrigerant frozen at }-80^{\circ} \mathrm{C} \\
\text { for } 24 \mathrm{~h})\end{array}$ & $\begin{array}{l}\text { Repeated sprint exercise } 5 \\
\text { x } 6 \text { s) before \& after two } \\
45 \text {-min bouts of football } \\
\text { specific intermittent } \\
\text { treadmill protocol }\end{array}$ & $\downarrow$ & $\downarrow$ TS \& RPE & $\begin{array}{l}\rightarrow \mathrm{T}_{\text {core }} \& \text { Tsk, } \rightarrow \\
\text { HR \& Bla \& Gluc } \\
\& \text { PRL \& Cortisol } \\
\& \text { PV \& Wc \& WL }\end{array}$ & $\begin{array}{l}\uparrow \text { Work load by } \\
39 \mathrm{~W}(6 \%)\end{array}$ \\
\hline $\begin{array}{l}\text { Minniti et al. } \\
\text { [19] }\end{array}$ & 8 males & $\begin{array}{l}30.5 \pm 0.1^{\circ} \mathrm{C}, 53 \pm 2 \% \\
\mathrm{RH}\end{array}$ & $\begin{array}{l}\text { Cold collar }(120 \mathrm{~g} \text { gel, } \\
\left.\text { frozen at }-80^{\circ} \mathrm{C} \text { for } 24-28 \mathrm{~h}\right)\end{array}$ & $\begin{array}{l}\text { Running } 75 \text { min at } 60 \% \\
\mathrm{VO}_{2 \max } \\
\& 15 \text { min TT running }\end{array}$ & NA & $\downarrow$ TS \& RPE & $\begin{array}{l}\rightarrow \mathrm{T}_{\text {core }}, \rightarrow \mathrm{HR} \& \\
\mathrm{VO}_{2} \& \text { Gluc \& } \\
\text { Cortisol }\end{array}$ & $\begin{array}{l}\uparrow \text { Distance by } \\
153 \mathrm{~m}(5 \%)\end{array}$ \\
\hline Desai \& & 8 male & $21.3 \pm 3.4^{\circ} \mathrm{C}$ & Ice bag ( $310 \mathrm{~g}$ ice) was & Table-tennis-specific & $\downarrow$ & $\rightarrow \mathrm{TS} \& \mathrm{RPE}$ & $\rightarrow \mathrm{HR} \& \mathrm{VO}_{2}$ & $\uparrow \operatorname{TPS}(15 \%)$ \\
\hline
\end{tabular}




\begin{tabular}{|c|c|c|c|c|c|c|c|c|}
\hline Bottoms [26] & players & $44.5 \pm 4 \% \mathrm{RH}$ & $\begin{array}{l}\text { applied three times in each } \\
\text { trial ( } 1 \text { min pre-exercise } \& \\
\left.\text { after the } 1^{\text {st }} \& 2^{\text {nd }} \text { bout }\right)\end{array}$ & $\begin{array}{l}\text { protocol } \\
(3 \text { bouts, } 660 \mathrm{~s})\end{array}$ & & & & \\
\hline $\begin{array}{l}\text { Zhang et al. } \\
\text { [27] }\end{array}$ & $\begin{array}{l}6 \text { males, } \\
1 \text { female }\end{array}$ & $\begin{array}{l}36^{\circ} \mathrm{C}, 50 \% \mathrm{RH} \\
\text { (running) } \& 20.7^{\circ} \mathrm{C}, \\
45 \% \mathrm{RH} \text { (recovery } \\
\& 6 \times 15 \mathrm{~m} \text { sprint \& } \\
\text { YYIR1) }\end{array}$ & $\begin{array}{l}\text { Half-time cooling using a } \\
\text { neck towel (placed in } 5^{\circ} \mathrm{C} \\
\text { ice water for } 10 \mathrm{~min} \text { ) }\end{array}$ & $\begin{array}{l}45 \text { min running \& } 15 \mathrm{~min} \\
\text { recovery }\end{array}$ & NA & $\downarrow \mathrm{TS}$ & $\begin{array}{l}\rightarrow \mathrm{T}_{\text {core }} \& \mathrm{HR}, \downarrow \mathrm{SR} \\
\& \text { dehydration }\end{array}$ & $\begin{array}{l}\uparrow \text { YYIR1 } \\
\text { distance }\end{array}$ \\
\hline $\begin{array}{l}\text { Tyler \& } \\
\text { Sunderland } \\
{[28]}\end{array}$ & 9 females & $\begin{array}{l}30.5 \pm 0.1^{\circ} \mathrm{C}, 53 \pm 2 \% \\
\mathrm{RH}\end{array}$ & $\begin{array}{l}\text { Cold collar }(120 \mathrm{~g} \text { gel, } \\
\left.\text { frozen at }-80^{\circ} \mathrm{C} \text { for } 24-28 \mathrm{~h}\right)\end{array}$ & $\begin{array}{l}\text { Running } 75 \text { min at } 60 \% \\
\mathrm{VO}_{2 \max } \\
\& 15 \text { min TT running }\end{array}$ & $\downarrow$ & $\downarrow$ TS \& RPE & $\begin{array}{l}\rightarrow \mathrm{T}_{\text {core }}, \rightarrow \mathrm{HR} \& \mathrm{SR} \\
\& \mathrm{Wc}\end{array}$ & $\begin{array}{l}\uparrow \text { Distance by } \\
146 \mathrm{~m}(5 \%)\end{array}$ \\
\hline $\begin{array}{l}\text { Colvin \& } \\
\text { Lokody [29] }\end{array}$ & $\begin{array}{l}1 \\
\text { triathlon } \\
\text { runner }\end{array}$ & $41^{\circ} \mathrm{C}, 50 \% \mathrm{RH}$ & Cooling collar $\left(454 \mathrm{~g}, 18^{\circ} \mathrm{C}\right)$ & Running TTE & $\downarrow$ & NA & $\downarrow \mathrm{T}_{\text {core }}$ & $\begin{array}{l}\uparrow \text { Time by } 17 \\
\min (51 \%)\end{array}$ \\
\hline $\begin{array}{l}\text { Gabrys et al. } \\
{[30]}\end{array}$ & 11 males & $40^{\circ} \mathrm{C}, 80 \% \mathrm{RH}$ & $\begin{array}{l}\text { Water cooling collar }(300 \\
\mathrm{cm}^{2}, \text { Tin }=14.8^{\circ} \mathrm{C}, \\
\text { Tout }=18.4^{\circ} \mathrm{C} \text {, flow rate: } 1.2 \\
\mathrm{~L} / \mathrm{min})\end{array}$ & $\begin{array}{l}\text { Graded cycloergometer } \\
\text { exercise at } 50 \mathrm{~W} \text {, increased } \\
\text { by } 50 \mathrm{~W} \text { every } 3 \text { min (till } \\
200 \mathrm{~W} \text { ) }\end{array}$ & NA & $\downarrow$ TD & $\begin{array}{l}\rightarrow \mathrm{T}_{\text {core }}, \rightarrow \mathrm{VO}_{2}, \uparrow \\
\mathrm{SV} \& \mathrm{CO}\end{array}$ & $\begin{array}{l}\uparrow \text { Work load by } \\
50 \mathrm{~W}(33 \%)\end{array}$ \\
\hline $\begin{array}{l}\text { Chalmers et } \\
\text { al. [31] }\end{array}$ & $\begin{array}{l}12 \\
\text { football } \\
\text { players }\end{array}$ & $\begin{array}{l}35^{\circ} \mathrm{C}, 55 \% \mathrm{RH}, \\
\mathrm{WBGT}=30^{\circ} \mathrm{C}\end{array}$ & $\begin{array}{l}\text { Ice towel ( } 2.5 \mathrm{~kg} \text { ice }) \text { was } \\
\text { applied } 2.5 \mathrm{~min} \text { at the } 30 \\
\text { min mark of each half }\end{array}$ & $\begin{array}{l}\text { Simulated football match } \\
(45 \mathrm{~min}+15 \text { min rest }+45 \\
\text { min })\end{array}$ & NA & $\rightarrow \mathrm{TS}, \downarrow \mathrm{RPE}$ & $\begin{array}{l}\downarrow \mathrm{T}_{\text {core }}, \rightarrow \mathrm{Tsk}, \downarrow \\
\mathrm{HR}\end{array}$ & NA \\
\hline $\begin{array}{l}\text { Hamada et } \\
\text { al. [32] }\end{array}$ & 7 males & $30 \pm 1^{\circ} \mathrm{C}, 40 \% \mathrm{RH}$ & $\begin{array}{l}\text { Ice pack cooling at bilateral } \\
\text { carotid ( } 500 \mathrm{~g} \text {, change every } \\
10 \mathrm{~min} \text {; applied at } 20 \text { th min) }\end{array}$ & $\begin{array}{l}\text { Cycling } 40 \text { min at } 60 \% \\
\mathrm{VO}_{2 \max }\end{array}$ & $\downarrow$ & $\downarrow \mathrm{TS}$ & $\begin{array}{l}\rightarrow \mathrm{T}_{\text {core }} \& \mathrm{Tsk}, \rightarrow \\
\mathrm{SkBF}, \uparrow \mathrm{HR}, \downarrow \mathrm{SR}\end{array}$ & NA \\
\hline \multirow[t]{2}{*}{$\begin{array}{l}\text { Torii et al. } \\
\text { [33] }\end{array}$} & 7 males & $30^{\circ} \mathrm{C}, 40 \% \mathrm{RH}$ & $\begin{array}{l}\text { Ice pack cooling at bilateral } \\
\text { carotid after } 20 \text { min exercise }\end{array}$ & $\begin{array}{l}\text { Cycling } 40 \mathrm{~min} \text { at } 60 \% \\
\text { PPO }\end{array}$ & $\downarrow$ & $\downarrow \mathrm{TS}$ & $\begin{array}{l}\rightarrow \mathrm{T}_{\text {core }} \& \mathrm{Tsk}, \rightarrow \\
\mathrm{HR} \& \mathrm{SKBF}, \downarrow \mathrm{T}_{\mathrm{ty}},\end{array}$ & NA \\
\hline & & & & & & & $\downarrow \mathrm{SR}$ & \\
\hline
\end{tabular}




\begin{tabular}{|c|c|c|c|c|c|c|c|c|}
\hline $\begin{array}{l}\text { Bouskill \& } \\
\text { Parsons [34] }\end{array}$ & 8 males & $\begin{array}{l}39.9 \pm 0.2^{\circ} \mathrm{C} \\
27.1 \pm 0.3 \% \mathrm{RH}\end{array}$ & $\begin{array}{l}\text { Water cooling collar } \\
\left(\text { Tin }=18.7 \pm 0.2^{\circ} \mathrm{C} \text {, }\right. \\
\text { Tout }=19.4 \pm 0.7^{\circ} \mathrm{C} \text {, flow rate: } \\
0.8 \mathrm{~L} / \mathrm{h})\end{array}$ & $\begin{array}{l}50 \mathrm{~min} \text { exercise } \\
\text { (step test to } 25 \mathrm{~cm} \text { height at } \\
60 \mathrm{bpm} \text { ) }\end{array}$ & $\downarrow$ & $\rightarrow \mathrm{TS}$ & $\begin{array}{l}\downarrow \mathrm{Tsk}, \uparrow \mathrm{HR}, \rightarrow \mathrm{SR} \\
\& \mathrm{WL}\end{array}$ & NA \\
\hline $\begin{array}{l}\text { Gordon et al. } \\
\text { [35] }\end{array}$ & $\begin{array}{l}10 \text { male } \\
\text { athletes }\end{array}$ & $21^{\circ} \mathrm{C}, 66.9 \% \mathrm{RH}$ & Cooling collar (T unknown) & $\begin{array}{l}\text { Running } 45 \text { min at } \mathrm{RPE}= \\
15\end{array}$ & NA & $\rightarrow \mathrm{RPE}$ & $\begin{array}{l}\downarrow \mathrm{T}_{\text {core }}, \downarrow \mathrm{SR}, \\
\rightarrow \mathrm{HR}\end{array}$ & NA \\
\hline $\begin{array}{l}\text { Kielblock et } \\
\text { al. [36] }\end{array}$ & 5 males & $40^{\circ} \mathrm{C}, 70.5 \% \mathrm{RH}$ & $\begin{array}{l}\text { Instant cold pack ( } \mathrm{T} \\
\text { unknown) }\end{array}$ & $\begin{array}{l}54 \mathrm{~W} \text { external work until } \\
\Delta \mathrm{T} \text { core }=+2{ }^{\circ} \mathrm{C}\end{array}$ & NA & NA & $\rightarrow \mathrm{T}_{\text {core }}, \rightarrow \mathrm{HR} \& \mathrm{BP}$ & NA \\
\hline
\end{tabular}

Note: $\rightarrow$ no change, $\uparrow$ increase, $\downarrow$ decrease, Bla blood lactate concentration, BP blood pressure, $C O$ cardiac output, Gluc glucose concentration, $H E X$ high-intensity exercise,

$H R$ heart rate, $N A$ not available, $P P O$ peak power output, $P R L$ blood prolactin concentration, $P V$ plasma volume, $R H$ relative humidity, $R P E$ rating of perceived exertion,

$S k B F$ skin blood flow, $S R$ sweat rate, $S V$ stroke volume, $T_{\text {core }}$ core temperature, $T D$ thermal discomfort, $T_{\text {neck }}$ neck skin temperature, $T P S$ total performance score, $T S$ thermal sensation, $T s k$ skin temperature, $T_{t y}$ tympanic membrane temperature, $T T$ time trial, $T T E$ time to exhaustion, $V O_{2}$ oxygen uptake, $V O_{2 m a x}$ maximal oxygen uptake, $W c$ water consumed, WL weight loss, YYIRI Yo-Yo intermittent recovery level 1 test, NA, not available. 
Table 2 Effect of head cooling on thermoregulatory responses and physical performance in the heat

\begin{tabular}{|c|c|c|c|c|c|c|c|c|}
\hline Study & Subjects & $\begin{array}{l}\text { Ambient } \\
\text { conditions }\end{array}$ & $\begin{array}{l}\text { Cooling } \\
\text { interventions }\end{array}$ & Exercise protocol & $\mathbf{T}_{\text {head }}$ & $\begin{array}{l}\text { Perceptual } \\
\text { outcomes }\end{array}$ & $\begin{array}{l}\text { Thermoregulatory } \\
\text { outcomes }\end{array}$ & $\begin{array}{l}\text { Performance } \\
\text { outcomes }\end{array}$ \\
\hline $\begin{array}{l}\text { Levels et al. } \\
\text { [37] }\end{array}$ & 10 cyclists & $\begin{array}{l}30^{\circ} \mathrm{C}, 50 \% \\
\mathrm{RH}\end{array}$ & $\begin{array}{l}\text { Head cooling (neoprene-covered } \\
\text { silicone cooling cap connected to } \\
\text { a cooling machine. } \mathrm{T}_{\text {coolant }}=-9 \text { to } \\
-10^{\circ} \mathrm{C} \text { ) }\end{array}$ & $\begin{array}{l}15 \mathrm{~km} \text { TT cycling at } 2 \mathrm{~W} / \text { body } \\
\text { mass }\end{array}$ & NA & $\begin{array}{l}\rightarrow \mathrm{TS} \& \mathrm{TD} \\
\& \mathrm{RPE}\end{array}$ & $\rightarrow \mathrm{T}_{\text {core }} \& \mathrm{Tsk}, \rightarrow \mathrm{HR}$ & $\begin{array}{l}\rightarrow \text { Exercise } \\
\text { time }\end{array}$ \\
\hline $\begin{array}{l}\text { Ansley et al. } \\
{[16]}\end{array}$ & 9 males & $\begin{array}{l}27-29^{\circ} \mathrm{C}, 40- \\
60 \% \mathrm{RH}\end{array}$ & $\begin{array}{l}\text { Head cooling ( } 3 \text { fans placed at } 50 \\
\mathrm{~cm} \text { from the face and head }+\mathrm{a} \\
\text { mist of water was sparyed over } \\
\text { the head at } 30 \mathrm{~s} \text { intervals) }\end{array}$ & Cycling TTE at $75 \% \mathrm{VO}_{2 \max }$ & $\downarrow$ & $\downarrow$ RPE & $\begin{array}{l}\rightarrow \mathrm{T}_{\text {core }}, \downarrow \mathrm{Tsk}, \rightarrow \mathrm{HR} \& \\
\text { Bla \& Gluc \& } \mathrm{VO}_{2} \& \\
\text { VE, } \downarrow \text { PRL }\end{array}$ & $\begin{array}{l}\uparrow \text { Time by } 21 \\
\min (51 \%)\end{array}$ \\
\hline $\begin{array}{l}\text { Coelho et al. } \\
\text { [38] }\end{array}$ & 15 males & $\begin{array}{l}35^{\circ} \mathrm{C}, 50 \% \\
\mathrm{RH}\end{array}$ & $\begin{array}{l}\text { Head cooling (cotton cap } \\
\text { containing a cold mixture [- } \\
20.2 \pm 1.8^{\circ} \mathrm{C} \text { ] of water and alcohol } \\
\text { gel, change every } 7 \text { min) for } 20 \\
\text { min prior to exercise }\end{array}$ & $5 \mathrm{Km}$ TT running & $\downarrow$ & $\begin{array}{l}\rightarrow \mathrm{TS} \& \\
\mathrm{RPE}\end{array}$ & $\begin{array}{l}\downarrow \mathrm{T}_{\text {core }}, \rightarrow \mathrm{Tsk}, \rightarrow \mathrm{HR} \& \\
\mathrm{SR}\end{array}$ & $\begin{array}{l}\uparrow \text { Time by }-2 \\
\min (7 \%)\end{array}$ \\
\hline $\begin{array}{l}\text { Walters et al. } \\
\text { [39] }\end{array}$ & 22 males & $\begin{array}{l}35 \pm 1^{\circ} \mathrm{C} \\
15 \pm 3 \% \mathrm{RH}\end{array}$ & $\begin{array}{l}\text { Head cooling (cooling fluid } \\
\text { through tubing and neoprene cap, } \\
\mathrm{T}_{\text {water }}=5-10^{\circ} \mathrm{C} \text { ) }\end{array}$ & $\begin{array}{l}\text { Cycling } 40 \text { min at } 65 \% \mathrm{VO}_{2 \max } \& 7 \\
\text { min recovery, graded exercise test } \\
(1 \mathrm{~W} \text { increased every } 2.5 \mathrm{~s} \text { until } \\
\text { exhaustion, cooling removed) }\end{array}$ & NA & $\rightarrow \mathrm{RPE}$ & $\rightarrow \mathrm{T}_{\text {core }}, \rightarrow \mathrm{HR} \& \mathrm{Bla}$ & $\begin{array}{l}\uparrow \text { Work load } \\
\text { by } 13 \mathrm{~W}(4 \%)\end{array}$ \\
\hline $\begin{array}{l}\text { Minett et al. } \\
\text { [40] }\end{array}$ & $\begin{array}{l}10 \text { male } \\
\text { athletes }\end{array}$ & $\begin{array}{l}33.0 \pm 0.7^{\circ} \mathrm{C}, \\
33.3 \pm 3.9 \% \\
\mathrm{RH}\end{array}$ & $\begin{array}{l}\text { Head cooling (ice towel soaked } \\
\text { in water }\left[5 \pm 0.5^{\circ} \mathrm{C}\right] \text { before being } \\
\text { placed over the head) }\end{array}$ & $\begin{array}{l}2 \text { x } 35 \text { min exercise spells } \\
\text { separated by } 15 \text { min recovery }\end{array}$ & NA & $\begin{array}{l}\downarrow \mathrm{TS} \& \\
\mathrm{RPE}\end{array}$ & $\rightarrow \mathrm{pH} \&$ Gluc \& $\mathrm{HCO}_{3}$ & $\begin{array}{l}\uparrow \text { Distance by } \\
43 \mathrm{~m}(4 \%)\end{array}$ \\
\hline Hyde [41] & $\begin{array}{l}7 \text { males \& } \\
7 \text { females }\end{array}$ & $\begin{array}{l}38.5 \pm 1.5^{\circ} \mathrm{C} \\
37.5 \pm 7.6 \% \\
\mathrm{RH}\end{array}$ & $\begin{array}{l}\text { Head cooling (cooling cap } \\
\text { connected to a cooling machine, } \\
\text { T unknown) }\end{array}$ & $\begin{array}{l}\text { Six bouts treadmill exercise }(3-4.5 \\
\text { mph at } 5 \% \text { inclination) }\end{array}$ & NA & NA & $\rightarrow \mathrm{T}_{\text {core }}, \rightarrow \mathrm{HR}$ & NA \\
\hline Desruelle \& & 7 males & $36^{\circ} \mathrm{C}, 29 \%$ & Head cooling $\left(10^{\circ} \mathrm{C}\right.$ air to the & Cycling $35 \mathrm{~min}$ at $90 \mathrm{~W}$ & $\downarrow$ & NA & $\rightarrow \mathrm{T}_{\text {core }}, \downarrow \mathrm{Tsk}, \rightarrow \mathrm{SR}$ & NA \\
\hline
\end{tabular}




\begin{tabular}{|c|c|c|c|c|c|c|c|c|}
\hline Candas [42] & & RH & hood, $12 \mathrm{~m} / \mathrm{s}$ ) & & & & & \\
\hline Watanuki[43] & 6 females & $\begin{array}{l}25^{\circ} \mathrm{C}, 56 \% \\
\mathrm{RH}\end{array}$ & $\begin{array}{l}\text { Head cooling (inlet } \mathrm{T}_{\text {water }}=15^{\circ} \mathrm{C} \\
\text { with a flow of } 1.2 \mathrm{~L} / \mathrm{min} \text { ) }\end{array}$ & $\begin{array}{l}\text { Cycling } 25 \mathrm{~min} \text { at } 25 \% \mathrm{VO}_{2 \max } \& \\
\text { cycling } 25 \mathrm{~min} \text { at } 50 \% \mathrm{VO}_{2 \max }\end{array}$ & $\downarrow$ & NA & $\downarrow \mathrm{HR} \& \mathrm{CO} \& \mathrm{VO}_{2}$ & NA \\
\hline $\begin{array}{l}\text { Katsuura et al. } \\
\text { [44] }\end{array}$ & 10 males & $30^{\circ} \mathrm{C}$ & $\begin{array}{l}\text { Head cooling (thermoelectric } \\
\text { cooled water circulating through } \\
\text { tubing, } \mathrm{T}_{\text {water }}=15^{\circ} \mathrm{C} \text { ) }\end{array}$ & Cycling 45 min at $40 \% \mathrm{VO}_{2 \max }$ & NA & NA & $\uparrow \mathrm{T}_{\text {core }}, \downarrow \mathrm{SR}, \rightarrow \mathrm{SkBF}$ & NA \\
\hline $\begin{array}{l}\text { Katsuura et al. } \\
\text { [44] }\end{array}$ & 10 males & $40^{\circ} \mathrm{C}$ & $\begin{array}{l}\text { Head cooling (thermoelectric } \\
\text { cooled water circulating through } \\
\text { tubing, } \mathrm{T}_{\text {water }}=15^{\circ} \mathrm{C} \text { ) }\end{array}$ & Passive heating & NA & NA & $\begin{array}{l}\downarrow \mathrm{T}_{\text {core }}, \downarrow \mathrm{HR} \& \mathrm{VO}_{2} \& \\
\mathrm{CO} \& \mathrm{SkBF}\end{array}$ & NA \\
\hline $\begin{array}{l}\text { Greenleaf et al. } \\
\text { [45] }\end{array}$ & 4 males & $\begin{array}{l}40.1^{\circ} \mathrm{C}, 40 \% \\
\mathrm{RH}\end{array}$ & $\begin{array}{l}\text { Head cooling (liquid cooling } \\
\text { headgear, T unknown) }\end{array}$ & Cycling $60 \mathrm{~min}$ at $45 \% \mathrm{VO}_{2 \max }$ & NA & NA & $\begin{array}{l}\rightarrow \mathrm{T}_{\text {core }}, \rightarrow \mathrm{HR} \& \mathrm{PP} \& \\
\text { Osmotic \& ES, } \uparrow \mathrm{PV}, \downarrow\end{array}$ & NA \\
\hline & & & & & & & SR & \\
\hline
\end{tabular}

Note: $\rightarrow$ no change, $\uparrow$ increase, $\downarrow$ decrease, Bla blood lactate concentration, $C O$ cardiac output, ES electrolyte shift, Gluc glucose concentration, HR heart rate, NA not

available, $P P$ plasma protein, $P P O$ peak power output, $P R L$ blood prolactin concentration, $P S I$ physiological Index of Strain, $P V$ plasma volume, $R H$ relative humidity, $R P E$ rating of perceived exertion, $S k B F$ skin blood flow, $S R$ sweat rate, $S V$ stroke volume, $T_{\text {core }}$ core temperature, $T D$ thermal discomfort, $T_{\text {head }}$ head skin temperature, $T S$ thermal sensation, $T s k$ skin temperature, $T T$ time trial, $T T E$ time to exhaustion, $V E$ minute ventilation, $V O_{2}$ oxygen uptake, $V O_{2 m a x}$ maximal oxygen uptake, $W c$ water consumed. NA, not available. 
Table 3 Effect of facial cooling on thermoregulatory responses and physical performance in the heat

\begin{tabular}{|c|c|c|c|c|c|c|c|c|}
\hline Study & Subjects & $\begin{array}{l}\text { Ambient } \\
\text { conditions }\end{array}$ & $\begin{array}{l}\text { Cooling } \\
\text { interventions }\end{array}$ & Exercise protocol & $\mathbf{T}_{\text {local }}$ & $\begin{array}{l}\text { Perceptual } \\
\text { outcomes }\end{array}$ & Thermoregulatory outcomes & $\begin{array}{l}\text { Performance } \\
\text { outcomes }\end{array}$ \\
\hline $\begin{array}{l}\text { Schlader et } \\
\text { al. [12] }\end{array}$ & 12 males & $\begin{array}{l}35^{\circ} \mathrm{C}, 48 \% \\
\mathrm{RH}\end{array}$ & $\begin{array}{l}\text { Face cooling }\left(20^{\circ} \mathrm{C} \text { air blown }\right. \\
\text { at } 0.74 \mathrm{~m} / \mathrm{s})\end{array}$ & Fixed RPE $=16$ & $\downarrow \mathrm{T}_{\text {face }}$ & $\begin{array}{l}\downarrow \mathrm{TS} \& \mathrm{TD}, \\
\rightarrow \mathrm{RPE}\end{array}$ & $\rightarrow \mathrm{T}_{\text {core }} \& \mathrm{Tsk}, \rightarrow \mathrm{HR} \& \mathrm{SR}$ & $\begin{array}{l}\uparrow \text { Total work by } \\
34 \mathrm{~kJ}(18 \%)\end{array}$ \\
\hline $\begin{array}{l}\text { Stevens et } \\
\text { al. [46] }\end{array}$ & 9 male runners & $\begin{array}{l}32.5 \pm 0.1^{\circ} \mathrm{C} \\
33.9 \pm 5.8 \% \mathrm{RH}\end{array}$ & $\begin{array}{l}\text { Intermittent facial water } \\
\text { spray }\left(\mathrm{T}_{\text {water }}=22^{\circ} \mathrm{C} \text { spraying }\right. \\
\text { once per km during the } \mathrm{TT} \\
[15 \text { sprays in total }])\end{array}$ & $5 \mathrm{~km}$ TT running & $\begin{array}{l}\downarrow \\
\mathrm{T}_{\text {forehead }}\end{array}$ & $\begin{array}{l}\downarrow \mathrm{TS}, \rightarrow \\
\mathrm{RPE}\end{array}$ & $\begin{array}{l}\rightarrow \mathrm{HR} \& \mathrm{Bla} \& \mathrm{VO}_{2} \& \mathrm{VE} \& \\
\mathrm{RER} \& \mathrm{SR}, \uparrow \mathrm{iEMG}\end{array}$ & $\begin{array}{l}\uparrow \text { Time by }-36 \mathrm{~s} \\
(2.4 \%)\end{array}$ \\
\hline $\begin{array}{l}\text { Schlader et } \\
\text { al. [47] }\end{array}$ & $\begin{array}{l}9 \text { males \& } 1 \\
\text { female }\end{array}$ & $\begin{array}{l}24 \pm 1^{\circ} \mathrm{C} \\
35 \pm 15 \% \mathrm{RH}\end{array}$ & $\begin{array}{l}\text { Face cooling (placing ice } \\
\text { water bag on forehead, eyes } \\
\& \text { cheeks) }\end{array}$ & Passive heating & $\begin{array}{l}\downarrow \\
\mathrm{T}_{\text {forehead }}\end{array}$ & NA & $\rightarrow \mathrm{HR} \& \mathrm{CO} \& \mathrm{SkBF}, \downarrow \mathrm{BP}$ & NA \\
\hline $\begin{array}{l}\text { Schlader et } \\
\text { al. [48] }\end{array}$ & $\begin{array}{l}3 \text { females (face- } \\
\text { cooling) \& } 6 \\
\text { females (Sham } \\
\text { trials) }\end{array}$ & $\begin{array}{l}24 \pm 1^{\circ} \mathrm{C} \\
35 \pm 15 \% \mathrm{RH}\end{array}$ & $\begin{array}{l}\text { Face cooling (placing ice } \\
\text { water bag on forehead, eyes } \\
\& \text { cheeks) }\end{array}$ & Supine position & $\begin{array}{l}\downarrow \\
\mathrm{T}_{\text {forehead }}\end{array}$ & NA & $\uparrow \mathrm{BP} \& \mathrm{FVR}, \rightarrow \mathrm{HR} \& \mathrm{CO}$ & NA \\
\hline $\begin{array}{l}\text { Mündel et } \\
\text { al. [49] }\end{array}$ & 10 males & $\begin{array}{l}33^{\circ} \mathrm{C}, 27 \pm 1 \% \\
\mathrm{RH}, \\
\text { fan speed: } 0.5 \\
\mathrm{~m} / \mathrm{s}\end{array}$ & $\begin{array}{l}\text { Face cooling (spraying cold } \\
\text { water mist }\left[4^{\circ} \mathrm{C}\right] \text { to maintain } \\
\mathrm{T}_{\text {face }}<28^{\circ} \mathrm{C} \text { ) }\end{array}$ & $\begin{array}{l}\text { Cycling } 40 \text { min at } 77- \\
78 \% \mathrm{VO}_{2 \max }\end{array}$ & $\begin{array}{l}\downarrow \\
\mathrm{T}_{\text {forehead }}\end{array}$ & $\begin{array}{l}\rightarrow \mathrm{TS}, \downarrow \\
\mathrm{RPE}\end{array}$ & $\begin{array}{l}\downarrow \mathrm{T}_{\text {core }}, \uparrow \mathrm{Tsk}, \downarrow \mathrm{HR} \& \\
\text { Dyspnea \& PRL \& Bla, } \rightarrow \mathrm{VO}_{2} \\
\& \text { WL \& SR \& Gluc \& PV }\end{array}$ & NA \\
\hline $\begin{array}{l}\text { Mündel et } \\
\text { al. [50] }\end{array}$ & $\begin{array}{l}12 \text { males \& } 4 \\
\text { females }\end{array}$ & $\begin{array}{l}58 \pm 1^{\circ} \mathrm{C} \\
13 \pm 3 \% \mathrm{RH} \\
\text { sauna }\end{array}$ & $\begin{array}{l}\text { Face cooling (spraying ice- } \\
\text { water mist }\left[4^{\circ} \mathrm{C}\right] \text { for } 10 \mathrm{~s} \text { at } 5 \\
\text { min intervals) }\end{array}$ & Passive heating & $\begin{array}{l}\downarrow \\
\mathrm{T}_{\text {forehead }}\end{array}$ & $\downarrow \mathrm{TS}$ & $\rightarrow \mathrm{T}_{\text {core }}, \downarrow \mathrm{Tsk}, \rightarrow \mathrm{HR}, \downarrow \mathrm{PRL}$ & NA \\
\hline $\begin{array}{l}\text { Armada-da- } \\
\text { Silva et al. } \\
\text { [51] }\end{array}$ & 10 males & $\begin{array}{l}35 \pm 1^{\circ} \mathrm{C}, 20 \% \\
\mathrm{RH}\end{array}$ & $\begin{array}{l}\text { Face cooling (cold water mist } \\
\text { using electric fan) }\end{array}$ & $\begin{array}{l}\text { Cycling } 14 \text { min at } 63 \% \\
\text { MPO }\end{array}$ & $\downarrow \mathrm{T}_{\text {face }}$ & $\begin{array}{l}\rightarrow \mathrm{TD}, \downarrow \\
\mathrm{RPE}\end{array}$ & $\begin{array}{l}\rightarrow \mathrm{T}_{\text {core }} \& \text { Tsk, } \rightarrow \text { HR \& Gluc \& } \\
\text { Haematocrit, } \downarrow \text { RPE legs \& }\end{array}$ & NA \\
\hline
\end{tabular}




\section{Face cooling ( cold wind}

Williams \&

Kilgour [52]

5 males

Not mentioned

$\left[0 \pm 2^{\circ} \mathrm{C}\right]$ from air

conditioning unit via

insulated tube $[0.2 \mathrm{~m}$

diameter])

Kratzing \& 6 males \& 4

Cross [53] females

$46^{\circ} \mathrm{C}$, low RH from tubing towards nose

under a face mask)
Supine cycling $30 \mathrm{~min}$ at

$35 \% \mathrm{VO}_{2 \max } \& 70 \%$

$\mathrm{VO}_{2 \max }$ $\mathrm{T}_{\text {forehead }}$

NA

(1)

Cycling $15 \mathrm{~min}$ at $25-32$

$\mathrm{km} / \mathrm{h}$ $\rightarrow \mathrm{T}_{\text {core }}, \downarrow \mathrm{Tsk}, \rightarrow \mathrm{SV} \& \mathrm{CO} \&$

$\mathrm{VO}_{2} \& \mathrm{VE}, \downarrow \mathrm{HR}, \uparrow \mathrm{BP}$

NA

Note: $\rightarrow$ no change, $\uparrow$ increase, $\downarrow$ decrease, Bla blood lactate concentration, BP blood pressure, CO cardiac output, FVR forearm vascular resistance, Gluc glucose

concentration, $H R$ heart rate, $i E M G$ integrated electromyography, $N A$ not available, $P P O$ peak power output, $P R L$ blood prolactin concentration, $P V$ plasma volume, $R E R$ respiratory exchange ratio, $R H$ relative humidity, $R P E$ rating of perceived exertion, $S k B F$ skin blood flow, $S R$ sweat rate, $S V$ stroke volume, $T_{c o r e}$ core temperature, $T_{l o c a l}$ local skin temperature, $T D$ thermal discomfort, $T_{\text {face }}$ face skin temperature, $T_{\text {forehead }}$ forehead skin temperature, $T S$ thermal sensation, $T s k$ skin temperature, $T T$ time trial, $T T E$ time to exhaustion, $V E$ minute ventilation, $V O_{2}$ oxygen uptake, $V O_{2 \max }$ maximal oxygen uptake, $W \mathrm{~L}$ weight loss. NA, not available. 
Table 4 Effect of combined neck, head and facial cooling on thermoregulatory responses and physical performance in the heat

\begin{tabular}{|c|c|c|c|c|c|c|c|c|}
\hline Study & Subjects & $\begin{array}{l}\text { Ambient } \\
\text { conditions }\end{array}$ & $\begin{array}{l}\text { Cooling } \\
\text { interventions }\end{array}$ & Exercise protocol & $\mathbf{T}_{\text {local }}$ & $\begin{array}{l}\text { Perceptual } \\
\text { outcomes }\end{array}$ & $\begin{array}{l}\text { Thermoregulatory } \\
\text { outcomes }\end{array}$ & $\begin{array}{l}\text { Performance } \\
\text { outcomes }\end{array}$ \\
\hline $\begin{array}{l}\text { Wiewelhove } \\
\text { et al. [54] }\end{array}$ & $\begin{array}{l}8 \text { male tennis } \\
\text { players }\end{array}$ & $\begin{array}{l}31.8 \pm 2.1^{\circ} \mathrm{C} \\
48.5 \pm 9.6 \% \mathrm{RH}\end{array}$ & $\begin{array}{l}\text { Neck \& facial cooling (ice-filled } \\
\text { damp towel \& electric fanning at } 1 \\
\text { m distance) }\end{array}$ & $\begin{array}{l}45 \text { min simulated tennis } \\
\text { match }\end{array}$ & $\begin{array}{l}\downarrow \\
\mathrm{T}_{\text {neck }} \\
\& \\
\mathrm{~T}_{\text {face }}\end{array}$ & $\downarrow \mathrm{TS}$ & $\downarrow \mathrm{HR}, \uparrow \mathrm{RR}$ & $\begin{array}{l}\rightarrow \text { Exercise } \\
\text { time }\end{array}$ \\
\hline $\begin{array}{l}\text { Simmons et } \\
\text { al. [55] }\end{array}$ & $\begin{array}{l}6 \text { males, } 3 \\
\text { females }\end{array}$ & $\begin{array}{l}34 \pm 1^{\circ} \mathrm{C},<30 \% \\
\mathrm{RH} \\
\text { sauna } \\
\text { temp }=68 \pm 3^{\circ} \mathrm{C}\end{array}$ & $\begin{array}{l}\text { Head \& face cooling (Ice packs } \\
\text { placed around whole head) }\end{array}$ & $\begin{array}{l}\text { Two 12-min cycling tests at } \\
70 \% \mathrm{VO}_{2 \max } \text { separated by a } \\
\text { passive heating period in } \\
\text { sauna }\end{array}$ & NA & $\downarrow \mathrm{TS} \& \mathrm{RPE}$ & $\downarrow \mathrm{T}_{\text {core }} \& \mathrm{Tsk}, \rightarrow \mathrm{HR}$ & $\begin{array}{l}\rightarrow \text { Exercise } \\
\text { time }\end{array}$ \\
\hline $\begin{array}{l}\text { Palmer et al. } \\
{[56]}\end{array}$ & $\begin{array}{l}14 \text { male } \\
\text { runners }\end{array}$ & $33^{\circ} \mathrm{C}, 55 \% \mathrm{RH}$ & $\begin{array}{l}\text { Head \& neck cooling (water- } \\
\text { perfused hood }\left(1.1 \mathrm{~L} / \mathrm{min}, 1^{\circ} \mathrm{C}, 6.2\right. \\
\mathrm{m} \text { PVC tubing) }\end{array}$ & $\begin{array}{l}\text { Running } 30 \text { min at } 60 \% \\
\mathrm{VO}_{2 \max } \text { followed by } 15 \mathrm{~min} \\
\text { running TT }\end{array}$ & NA & $\begin{array}{l}\downarrow \mathrm{TS} \& \mathrm{TC}, \\
\rightarrow \mathrm{RPE}\end{array}$ & $\downarrow \mathrm{T}_{\text {core }}, \rightarrow \mathrm{HR}$ & $\begin{array}{l}\uparrow \text { Distance } \\
(3.3 \%)\end{array}$ \\
\hline $\begin{array}{l}\text { Gordon et al. } \\
\text { [57] }\end{array}$ & 14 males & $35^{\circ} \mathrm{C}, 50 \% \mathrm{RH}$ & $\begin{array}{l}\text { Head \& neck cooling (water- } \\
\text { perfused hood \& neck cooling, } \\
\text { Tin }=3^{\circ} \mathrm{C} \text { ) }\end{array}$ & $\begin{array}{l}\text { Cycling } 60 \text { min at } 50 \% \\
\mathrm{VO}_{2 \max }\end{array}$ & $\begin{array}{l}\downarrow \\
\mathrm{T}_{\text {neck }}\end{array}$ & $\downarrow \mathrm{TS}$ & $\begin{array}{l}\rightarrow \mathrm{T}_{\text {core }}, \rightarrow \mathrm{MVC}, \uparrow \mathrm{PF}, \\
\downarrow \mathrm{MVF} \& \mathrm{CAR} \& \mathrm{CF},\end{array}$ & NA \\
\hline $\begin{array}{l}\text { Goosey- } \\
\text { Tolfrey et al. } \\
{[58]}\end{array}$ & $\begin{array}{l}8 \text { wheelchair } \\
\text { tennis } \\
\text { players }\end{array}$ & $\begin{array}{l}30.4 \pm 0.6^{\circ} \mathrm{C} \\
54 \pm 3.8 \% \mathrm{RH}\end{array}$ & $\begin{array}{l}\text { Head \& neck cooling (water } \\
\text { absorbing crystals, refreshed every } \\
10 \text { min, T unknown) }\end{array}$ & $\begin{array}{l}60 \text { min intermittent sprint } \\
\text { trials }\end{array}$ & NA & $\downarrow \mathrm{TS} \& \mathrm{RPE}$ & $\downarrow \mathrm{Wc}, \rightarrow \mathrm{HR} \& \mathrm{Bla}$ & NA \\
\hline $\begin{array}{l}\text { Simmons et } \\
\text { al. [59] }\end{array}$ & $\begin{array}{l}6 \text { males, } 4 \\
\text { females }\end{array}$ & $\begin{array}{l}25^{\circ} \mathrm{C}, 50 \% \mathrm{RH} \\
\text { increased to } \\
45^{\circ} \mathrm{C}, 50 \% \mathrm{RH}\end{array}$ & $\begin{array}{l}\text { Head \& neck cooling (water } \\
\text { conditioned balaclava, } \\
\mathrm{T}_{\text {water }}==3^{\circ} \mathrm{C} \text { ) }\end{array}$ & Passive heating & $\begin{array}{l}\downarrow \\
\mathrm{T}_{\text {neck }}\end{array}$ & $\downarrow \mathrm{TD}$ & $\downarrow \mathrm{HR}, \uparrow \mathrm{SV}, \rightarrow \mathrm{CO}$ & NA \\
\hline $\begin{array}{l}\text { Ronald et al. } \\
\text { [60] }\end{array}$ & $\begin{array}{l}10 \text { males, } 10 \\
\text { females }\end{array}$ & $\begin{array}{l}30 \pm 1^{\circ} \mathrm{C}, 54 \pm 5 \% \\
\mathrm{RH}\end{array}$ & $\begin{array}{l}\text { Head \& neck cooling (evaporating } \\
\text { ice water absorbed by material } \\
\text { [polin fabric cover \& ties placed at }\end{array}$ & $\begin{array}{l}\text { Cycling } 30 \text { min at } 60 \% \\
\mathrm{VO}_{2 \max }\end{array}$ & $\begin{array}{l}\downarrow \\
\mathrm{T}_{\text {head }}\end{array}$ & $\rightarrow \mathrm{RPE}$ & $\begin{array}{l}\rightarrow \mathrm{T}_{\text {core }} \& \mathrm{Tsk}, \rightarrow \mathrm{HR} \& \\
\mathrm{VO}_{2} \& \mathrm{SR} \& \mathrm{PV} \& \mathrm{BP}\end{array}$ & NA \\
\hline
\end{tabular}


forehead \& neck bandanna tied

around neck])

Note: $\rightarrow$ no change, $\uparrow$ increase, $\downarrow$ decrease, Bla blood lactate concentration, $B P$ blood pressure, $C A R$ central activation ratio, $C F$ central fatigue, $C O$ cardiac output, $G l u c$ glucose concentration, $H R$ heart rate, $M V C$ maximal voluntary contraction, $M V F$ maximal voluntary force, $N A$ not available, $P F$ peripheral fatigue, $P P O$ peak power output, $P R L$ blood prolactin concentration, $P V$ plasma volume, $R H$ relative humidity, $R P E$ rating of perceived exertion, $R R$ ratings of recovery, $S k B F$ skin blood flow, $S R$ sweat rate, $S V$ stroke volume, $T_{\text {core }}$ core temperature, $T D$ thermal discomfort, $T_{\text {face }}$ face skin temperature, $T_{\text {head }}$ head skin temperature, $T_{\text {local }}$ local skin temperature, $T_{\text {neck }}$ neck skin temperature, $T S$ thermal sensation, $T s k$ skin temperature, $T T$ time trial, $T T E$ time to exhaustion, $V O_{2}$ oxygen uptake, $V O_{2 m a x}$ maximal oxygen uptake, $W c$ water consumed. NA, not available. 